\title{
RUMINAL METHANE EMISSION BY DAIRY CATTLE IN SOUTHEAST BRAZIL
}

\author{
Márcio dos Santos Pedreira ${ }^{1}$; Odo Primavesi²; Magda Aparecida Lima ${ }^{3}$; Rosa Frighetto 3 ; \\ Simone Gisele de Oliveira ${ }^{4 *}$; Telma Teresinha Berchielli ${ }^{5}$ \\ ${ }^{1}$ UESB - Depto. de Tecnologia Rural e Animal - 45700-000 - Itapetinga, BA - Brasil. \\ ${ }^{2}$ Embrapa Sudeste - 13560-970, São Carlos, SP - Brasil. \\ ${ }^{3}$ Embrapa Meio Ambiente - 13820-000, Jaguariúna, SP - Brasil. \\ ${ }_{5}^{4}$ UFPR - Depto. de Zootecnia, R. dos Funcionários, 1540 - 80035-050 - Curitiba, PR - Brasil. \\ ${ }^{5}$ UNESP/FCAV - Depto. de Zootecnia - 14884-900 - Jaboticabal, SP - Brasil. \\ *Corresponding author<sgoliveira@ufpr.br>
}

\begin{abstract}
Ruminal gases, particularly methane, generated during the fermentative process in rumen, represent a partial loss of feed energy and are also pointed to as an important factors in greenhouse effect. This study aimed at quantifying methane $\left(\mathrm{CH}_{4}\right)$ emission rates from lactating and dry cows and heifers, 24 month-old in average, on pasture under Southeast Brazil tropical conditions, using the tracer gas technique, sulphur hexafluoride $\left(\mathrm{SF}_{6}\right)$, four animals per category, distributed in four blocks. Measurements were performed in February and June, 2002, with Holstein and Brazilian Dairy Crossbred (Holstein 3/4 X Gir (Zebu) 1/4), maintained on fertilized Tanzania-grass (Panicum maximum Jacq. cv. Tanzania) and fertilized Brachiaria-grass (Brachiaria decumbens cv. Basilisk) pastures. Heifers of both breeds were maintained on unfertilized Brachiaria-grass to simulate conditions of extensive cattle farming systems. $\mathrm{CH}_{4}$ and $\mathrm{SF}_{6}$ levels were measured with gas chromatography. Differences in $\mathrm{CH}_{4}$ emissions were measured $(p<0.05)$ for genetical groups. Holstein produced more methane $(299.3$ $\left.\mathrm{g}_{\text {day }}{ }^{-1}\right)$ than the Crossbred $\left(264.2 \mathrm{~g} \mathrm{day}^{-1}\right)$. Lactating cows produced more methane $\left(353.8 \mathrm{~g} \mathrm{day}^{-1}\right)$ than dry cows $\left(268.8 \mathrm{~g} \mathrm{day}^{-1}\right)$ and heifers $\left(222.6 \mathrm{~g}\right.$ day $\left.^{-1}\right)$. Holstein, with greater milk production potential, produced less $\mathrm{CH}_{4}(p<0.05)$ per unit of dry matter intake $\left(19.1 \mathrm{~g} \mathrm{~kg}^{-1}\right)$ than the Crossbred $\left(22.0 \mathrm{~g} \mathrm{~kg}^{-1}\right)$. Methane emission by heifers grazing fertilized pasture (intensive system) was $222.6 \mathrm{~g}$ day $^{-1}$, greater $(p<0.05)$ than that of heifers on unfertilized pasture $\left(179.2 \mathrm{~g} \mathrm{day}^{-1}\right)$. Methane emission varied as function of animal category and management intensity of production system.
\end{abstract}

Key words: feeding, genetical group, sulphur hexafluoride, tropical pastures

\section{EMISSÃO DE METANO RUMINAL POR BOVINOS LEITEIROS NO SUDESTE DO BRASIL}

RESUMO: Gases gerados durante o processo de fermantação ruminal, metano em particular, representam não só uma perda parcial de energia da alimentação como também são apontados como importantes fatores do efeito-estufa. Quantificaram-se as taxas de emissão de metano $\left(\mathrm{CH}_{4}\right)$ ruminal por vacas em lactação, vacas secas e novilhas com idade média de 24 meses, em pastejo sob condições tropicais do sudeste brasileiro, utilizando a técnica do gás traçador hexafluoreto de enxôfre ( $\left.\mathrm{SF}_{6}\right)$. Foram utilizados quatro animais para cada categoria, distribuídos em quatro blocos. As medições foram realizadas em fevereiro e junho de 2002, com animais da raça Holandesa e Mestiça Leiteira Holandês 3/4 x Gir 1/4 Mestiças, mantidos em pastagem de capim-Tanzânia (Panicum maximum Jacq. cv. Tanzania) e capimbraquiária (Brachiaria decumbens cv. Basilisk) adubadas, e também novilhas de ambas as raças em pastagens de capim-brachiaria sem adubação, simulando as condições de produção extensiva. As concentrações de $\mathrm{CH}_{4}$ e $\mathrm{SF}_{6}$ foram determinadas por cromatografia gasosa. Foram encontradas diferenças na emissão de metano $(p<0,05)$ entre os grupos genéticos. Animais da raça holandesa produziram mais metano $\left(299,3 \mathrm{~g} \mathrm{dia}^{-1}\right)$ que as mestiças $\left(264,2 \mathrm{~g} \mathrm{dia}^{-1}\right)$. Vacas secas e novilhas produzem menos metano $\left(\mathrm{g} \mathrm{dia}^{-1}\right)$ que vacas em lactação. A média de emissão de metano $\left(\mathrm{g}\right.$ dia $\left.^{-1}\right)$ pelas vacas secas e novilhas foi de 268,8 e 222,6 g respectivamente e as vacas em lactação 353,8 g. Os animais da raça holandesa, com maior potencial de produção de leite, perderam menos $\mathrm{CH}_{4}(p<0,05)$ por unidade de matéria seca ingerida $\left(19,1 \mathrm{~g} \mathrm{~kg}^{-1}\right)$ que as mestiças $\left(22,0 \mathrm{~g} \mathrm{~kg}^{-1}\right)$. A produção de metano pelas novilhas mantidas em pastagens adubadas (sistema intensivo) foi de 222,6 $\mathrm{g} \mathrm{dia}^{-1}$, maior $(p<0,05)$ que os animais desta categoria em pastagens não adubadas $\left(179,2 \mathrm{~g} \mathrm{dia}^{-1}\right)$. A produção de metano variou em função da categoria de animal e pelo sistema de produção imposto aos animais.

Palavras-chave: manejo alimentar, grupo genético, hexafluoreto de enxofre, pastagem tropical 


\section{INTRODUCTION}

Ruminal gases yield are correlated to the microbial activity in rumen, and methane, a gas generated during the fermentative process in rumen, represents a partial loss of feed energy, with an accepted mean value of $6.5 \%$ of the ingested gross energy (IPCC, 2006), varying from $2 \%$ by animals feeding on highgrain diets, to $12 \%$ when low quality forage is fed (Johnson \& Johnson, 1995; Johnson et al., 2007). Methane $\left(\mathrm{CH}_{4}\right)$ is also pointed as an important factor on greenhouse effect, with enteric methane losses by farmed ruminant accounting for about one fourth of all anthropogenic emissions (Smith et al., 2007; Lassey, 2008).

Methane production of grazing cattle can be affected by management practices and production level. When the objective is weight gain, daily methane production by animal would be greater than in systems targeting production per hectare. These differences occur partially because of variation in forage availability in both systems. Considering methane emission by product unit (milk yield or weight gain per animal) values would be lower where gains per animal are greater, but methane yield by surface area will be larger (Kurihara et al., 1999).

Different methane amounts may be produced by Bos indicus, Bos taurus and their breeds. These variations may be associated to the different characteristics of animals, like ruminal volume, feed selection capacity, retention time of feed in rumen, and associations of factors linked to lower or greater digestion capacity of fibers in feed (Lassey et al., 2002).

Production phases may affect methane losses, linked to dry matter intake. Considering that feed intake is a function of body condition, pregnancy and lactating period (Mathison et al., 1995), distinct ruminal methane amount were expected from each phase (Moss, 1994). Abiotic factors that affect animal intake behavior as well as forage quality may also be regarded. So, methane production in different regions may differ, mainly between tropical and temperate climate environments.

Bovine ruminal methane emissions, under tropical conditions, at the moment, were estimated, considering only feed characteristics and production potential of animals. Considering that some environmental factors are related with these characteristics, real methane emissions may be different from these estimates, as observed by Kurihara et al. (1999).

Studies quantifying methane and analyzing factors that may reduce the production of this gas in tropical environment, as an opportunity to improve the efficiency of energy utilization of feed, are timely. Thus, this study aimed to quantify, the production of meth- ane by ruminal dairy cattle kept on pasture in Brazilian tropical conditions of Southeast Brazil.

\section{MATERIALAND METHODS}

Measurements were performed at São Carlos $\left(22^{\circ} 01^{\prime} \mathrm{S}, 47^{\circ} 53^{\prime} \mathrm{W}, 856 \mathrm{~m}\right.$ altitude), SP, southeastern Brazil. The climate of the region is tropical with wet summer and dry winter (Aw) or hot-dry winter (Cwa) (Köppen, 1948), and original vegetation of the Cerrado biome, with low fertility soils.

Trials were set up in in intensive system, with fertilized pastures plus concentrate diets. Experimental design consisted of four randomized blocks, represented by consecutive weeks, main plots represented by two breeds - Holstein and Holstein $3 / 4 \times$ Gir (Zebu) $1 / 4$ - Crossbred - and three categories: lactating cows, dry cows and heifers; seasons represented subplots in time, and treatments consisted of genetic groups: heifers, dry cows and dairy cows, one animal per treatment. Samples were taken twice a day (from 7 to 19 $\mathrm{h}$ from 19 to $7 \mathrm{~h}$ ) for five days along four weeks each season, in February (summer) and June (autumn). The two daily measurements consisted of ten sub-samples in the lieu of replications.

Mean live weight of animals tested, as well as mean milk yield of lactating cows are presented in Table 1 . Lactating cows were in the third or fourth calving, and the fourth or fifth week of lactation. Mean age of heifers were 24 months. Climatic characteristics of seasons appear in Table 2.

During summer, both lactating and dry Holstein cows, and half of the Holstein and Crossbred heifers were maintained on Tanzania-grass (Panicum maxicum Jacq. cv. Tanzania) pasture, fertilized with $400 \mathrm{~kg} \mathrm{ha}^{-1}$ of $\mathrm{N}$ and $\mathrm{K}_{2} \mathrm{O}$ each splitted five times after grazing, with an initial liming to reach base saturation of $60 \%$ and phosphorus to reach a content of $15 \mathrm{mg} \mathrm{kg}^{-1}$ soil, after resin method, and under one day grazing pressure of 10.8 animal units (AU, $450 \mathrm{~kg}$ of live weight) per hectare (ha), and 35 days of resting time. Other heifers were maintained on Brachiaria-grass (Brachiaria decumbens cv. Basilisk) pasture, without fertilizer and under a continuous grazing pressure of 1.5 $\mathrm{AU} \mathrm{ha}^{-1}$ (extensive production system). The lactating Crossbred cows were maintained on fertilized Brachiaria-grass pasture, under the same soil fertility conditions of Tanzania grass pasture, with one day grazing pressure of $10.8 \mathrm{AU} \mathrm{ha}^{-1}$, and 30 days of resting time for the forage. Pastures presented good forage availability, with uniform soil covering and height, without occurrence of weeds. Extensively managed pasture for heifers presented some weeds but maintained good soil covering with forage plants. 
Table 1 - Mean live weight and milk production of experimental units, with respective standard deviation.

\begin{tabular}{|c|c|c|c|c|}
\hline \multirow{2}{*}{ Animal category } & Live weight & SD & Milk production & SD \\
\hline & \multicolumn{4}{|c|}{ Summer } \\
\hline Holstein lactating cow & 571.5 & 72 & 22.7 & 3.9 \\
\hline Crossbred lactating cow & 478.5 & 86 & 13.3 & 2.1 \\
\hline Holstein dry cow & 605.0 & 18 & - & \\
\hline Crossbred dry cow & 480.0 & 52 & - & \\
\hline Holstein heifer ${ }^{1}$ & 501.5 & 78 & - & \\
\hline Crossbred heifer ${ }^{1}$ & 365.0 & 53 & - & \\
\hline Holstein heifer ${ }^{2}$ & 459.0 & 60 & - & \\
\hline \multirow[t]{2}{*}{ Crossbred heifer ${ }^{2}$} & 373.5 & 37 & - & \\
\hline & \multicolumn{4}{|c|}{ Fall } \\
\hline Holstein lactating cow & 569.7 & 44 & 24.3 & 12.5 \\
\hline Crossbred lactating cow & 474.2 & 52 & 9.7 & 2.4 \\
\hline Holstein dry cow & 641.7 & 15 & - & \\
\hline Crossbred dry cow & 521.7 & 70 & - & \\
\hline Holstein heifer ${ }^{1}$ & 520.0 & 80 & - & \\
\hline Crossbred heifer ${ }^{1}$ & 399.0 & 48 & - & \\
\hline Holstein heifer ${ }^{2}$ & 432.0 & 36 & - & \\
\hline Crossbred heifer ${ }^{2}$ & 388.5 & 28 & - & \\
\hline
\end{tabular}

${ }^{1}$ Intensive production system. ${ }^{2}$ Extensive production system. SD=Standard deviation, using four replications, represented by one animal each.

Table 2 - Mean climatic characteristics during experimental seasons.

\begin{tabular}{|c|c|c|c|c|c|c|c|}
\hline \multirow{2}{*}{ Period } & \multirow{2}{*}{ Rain } & \multicolumn{4}{|c|}{ Temperature } & \multirow{2}{*}{ Relative air Humidity } & \multirow{2}{*}{ Evaporation (Piché) } \\
\hline & & Maximum & Minimum & Mean & Amplitude & & \\
\hline & $\mathrm{mm}$ & \multicolumn{4}{|c|}{ 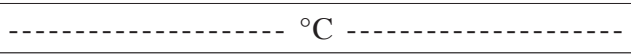 } & $\%$ & $\mathrm{~mm}$ \\
\hline & \multicolumn{7}{|c|}{ Summer } \\
\hline Value & 644 & 28.3 & 18.5 & 23.4 & 9.8 & 81 & 268 \\
\hline \multirow[t]{2}{*}{2002} & 677 & 28.1 & 18.5 & 23.3 & 9.6 & 81 & 350 \\
\hline & \multicolumn{7}{|c|}{ Fall } \\
\hline Value & 142 & 25.4 & 14.2 & 19.8 & 11.2 & 74 & 321 \\
\hline 2002 & 42 & 28.0 & 15.9 & 22.0 & 12.1 & 75 & 481 \\
\hline
\end{tabular}

Note: Total values are considered for rain and evaporation; mean values for temperature and air humidity.

Holstein lactating cows received daily $1 \mathrm{~kg}$ concentrate per each $3 \mathrm{~L}$ milk, and Crossbred lactating cows grazing fertilized Brachiaria pasture received $3.4 \mathrm{~kg}$ per cow. Dry cows and heifers of both breeds maintained on Tanzania-grass received $2 \mathrm{~kg}$ of concentrate per animal. Heifers of both breeds grazing not fertilized Brachiaria-grass pasture did not receive concentrate, simulating the main Brazilian cattle raising conditions. This experiment did not reach extreme negative structural pasture conditions (lower forage mass, highest fiber and lowest crude protein). Intensive and extensive, were terms used to identify pasture fertilizer use and use intensity for the category heifers. Lactating cows of both breeds were used as comparison criterion for dairy production systems with greater or lower technological level, not specifically to compare breeds, since they were submitted to different diets as the production capacity is not the same.

In fall, Holstein lactating cows were fed with corn silage, $10 \mathrm{~kg}$ dry matter (DM) animal ${ }^{-1} \mathrm{day}^{-1}$, and the Crossbred with chopped grain millet, $8 \mathrm{~kg}$ DM ani$\mathrm{mal}^{-1}$ day $^{-1}$, maintaining the same concentrate diet of their specific herd, adjusted to production capacity and daily requirements. Seasonal difference was the change of feeding lactating cows from grass forage to silage. The amount of concentrate remained the same as in summer. Dry cows and heifers were fed as in summer.

Forage was sampled after McMeniman (1997), by pooling 20 randomed $0.50 \times 0.50 \mathrm{~m}$-sub-samples cut 
to near soil surface, to estimate forage yield per hectare, and another sample simulating grazing, after following animals during grazing, avoiding disturbance of grazing behavior, and identifying carefully consummated plant parts. More specifically by verifying plant structure remaining at one site after grazing, and harvesting forage samples at a close site like at the grazed site (McMeniman, 1997), to get similar forage chemical quality and digestibility. Also corn silage, grain millet and concentrate were sampled for chemical analysis (McMeniman (1997). After $48 \mathrm{~h}$ pre-drying in oven at $60^{\circ} \mathrm{C}$ with forced air circulation, samples were ground in a Wiley mill with a $1 \mathrm{~mm}$ sieve, and finally dried during $8 \mathrm{~h}$ at $105^{\circ} \mathrm{C}$. Pre-dried samples were used to check DM content, crude protein $(\mathrm{CP})$ after the Dumas combustion method (Etheridge et al., 1998) and neutral detergent fiber (NDF), acid detergent fiber (ADF), and lignin, with the sequential method described by Soest et al. (1991). For NDF evaluation was used heat stable amylase and sodium sulphite. Lignin content was calculated after analyzing the cellulose content in sulphuric acid at 72\% (Soest, 1994), considering the difference between weight loss of ADF after analysis and the incinerated residue. Ash were obtained by incinerating samples at $600^{\circ} \mathrm{C}$, and organic matter $(\mathrm{OM})$ calculated $(\mathrm{OM}=100-$ ash $)$. Organic matter "in vitro" digestibility (OMIVD) was obtained using Tilley \& Terry (1963) method. Dry matter intake was estimated for each animal using NRC (2001) dairy cattle model.

Forage yield, and feed quality and digestibility data of both experimental periods are displayed in Tables 3 and 4. Prior to the ruminal air sampling, animals were adapted during $15 \mathrm{~d}$ to the collection-store system (holder and canister), to avoid stress influence on the results, mainly related to DM intake.

The sulphur hexafluoride $\left(\mathrm{SF}_{6}\right)$ tracer gas method, described by Johnson et al. (1994, 2007) were used to sample and quantify methane $\left(\mathrm{CH}_{4}\right)$ emission. Permeation capsules with known $\mathrm{SF}_{6}$ emission rates were prepared by gravimetry, measuring the mean weight loss (considering four decimals) during four consecutive weeks and allowing a standard deviation of a maximum of 5\%. Considerations of Lassey (2001) about the capsules life length were regarded. Calibrated capsules were housed in the experimental animal's rumen. Used canister was a closed tube $\left(0.002642 \mathrm{~m}^{3}\right.$ volume $)$ prepared with a $60 \mathrm{~mm}$ outer diameter class 20 brown PVC, pre-evacuated. The sampling system with a $0.0762 \mathrm{~mm}$ inner diameter capillary tubing, fixed on a holder, was calibrated to fill the canister with around half an atmosphere each sampling period (12 h). The sampling system was connected to the canister with a quick connect.

After animal adaptation to the collection and store apparatus, the $2 \times 12 \mathrm{~h}$ eructed ruminal gas was collected along five consecutive days, in two seasons. An identical apparatus was placed on the fence to allow the measurement of background $\mathrm{CH}_{4}$ levels in air. Since background $\mathrm{SF}_{6}$ concentration at field level were under the limit of quantification (in the cases it was detected, concentration was around 2.3 to $3.2 \mathrm{ppt}$ ), they were not considered, certainly different from experiments running in confinements.

Methane concentrations were measured with a gas chromatograph HP6890, equipped with a flame ionization detector (FID) and megabore column $(0.53 \mu \mathrm{m}$, $30 \mathrm{~m}$ ) Plot HP-AI/M; and with an electron capture de-

Table 3 - Yield and quality characteristics of forage delivered to animals during experimental period.

\begin{tabular}{|c|c|c|c|c|c|c|c|c|}
\hline Feed & FY & $\mathrm{DM}$ & $\mathrm{OM}$ & $\mathrm{CP}$ & NDF & $\mathrm{ADF}$ & LIG & OMIVD \\
\hline & $\mathrm{kg} \mathrm{ha}^{-1}$ & \multicolumn{7}{|c|}{ - } \\
\hline & \multicolumn{8}{|c|}{ Summer } \\
\hline Tanzania $^{1}$ & 3,452 & 18.7 & 89.9 & 12.9 & 62.5 & 32.1 & 5.2 & 57.3 \\
\hline Tanzania $^{2}$ & 3,982 & 19.9 & 90.0 & 15.1 & 64.2 & 34.2 & 5.1 & 54.7 \\
\hline Brachiaria $^{3}$ & 3,734 & 30.6 & 91.1 & 7.2 & 68.6 & 34.6 & 7.2 & 48.0 \\
\hline \multirow[t]{2}{*}{ Brachiaria $^{4}$} & 3,486 & 34.8 & 92.0 & 6.5 & 71.9 & 36.2 & 6.6 & 40.9 \\
\hline & \multicolumn{8}{|c|}{ Fall } \\
\hline Corn silage & - & 34.6 & 96.2 & 7.5 & 47.9 & 25.6 & 4.9 & 57.5 \\
\hline Choped Millet & - & 17.9 & 91.2 & 13.0 & 60.4 & 33.3 & 5.7 & 52.8 \\
\hline Tanzania $^{2}$ & 1,913 & 26.8 & 92.6 & 12.5 & 66.5 & 33.6 & 7.0 & 55.8 \\
\hline Brachiaria $^{4}$ & 2,481 & 34.8 & 93.1 & 6.2 & 70.1 & 33.5 & 7.9 & 49.8 \\
\hline
\end{tabular}

$\mathrm{FY}=$ Forage yield $; \mathrm{DM}=$ Dry matter $\mathrm{OM}=$ Organic matter $\mathrm{CP}=$ Crude protein $; \mathrm{NDF}=$ Neutral detergent fiber; $\mathrm{ADF}=\mathrm{Acid}$ detergent fiber; LIG = Lignin; OMIVD = Organic matter "in vitro" digestibility. ${ }^{1}$ Tanzania grass, fertilized and grazed by Holstein lactating cows. ${ }^{2}$ Tanzania grass, fertilized and grazed by both breed dry cows and heifers. ${ }^{3}$ Brachiaria grass, fertilized and grazed by Crossbred lactating cows. ${ }^{4}$ Brachiaria grass, not fertilized and grazed by both breed heifers. 
Table 4 - Quality characteristics of concentrate delivered to animals during experimental period.

\begin{tabular}{|c|c|c|c|c|c|c|c|}
\hline Feed & $\mathrm{DM}$ & $\mathrm{OM}$ & $\mathrm{CP}$ & NDF & $\mathrm{ADF}$ & LIG & OMIVD \\
\hline & \multicolumn{7}{|c|}{ Summer } \\
\hline Concentrate $^{1}$ & 86.3 & 94.1 & 27.1 & 23.3 & 14.5 & 1.5 & 75.2 \\
\hline Concentrate $^{2}$ & 94.6 & 94.5 & 21.6 & 27.9 & 15.3 & 1.4 & 64.7 \\
\hline \multirow[t]{2}{*}{ Concentrate $^{3}$} & 94.5 & 94.5 & 21.6 & 27.9 & 15.3 & 1.5 & 70.7 \\
\hline & & & & Fall & & & \\
\hline Concentrate $^{1}$ & 89.0 & 94.9 & 25.4 & 33.6 & 9.3 & 0.8 & 73.9 \\
\hline Concentrate $^{2}$ & 90.4 & 95.4 & 21.8 & 31.1 & 8.8 & 0.9 & 68.3 \\
\hline Concentrate $^{3}$ & 90.4 & 95.5 & 20.8 & 32.3 & 9.4 & 0.9 & 64.7 \\
\hline
\end{tabular}

$\mathrm{DM}=$ Dry matter; $\mathrm{OM}=$ Organic matter $\mathrm{CP}=$ Crude protein; $\mathrm{NDF}=$ Neutral detergent fiber; $\mathrm{ADF}=$ Acid detergent fiber; $\mathrm{LIG}=\mathrm{Lignin}$; OMIVD = Organic matter "in vitro" digestibility. ${ }^{1}$ Concentrate used for Holstein lactating cows. ${ }^{2}$ Concentrate used for Crossbred lactating cows. ${ }^{3}$ Concentrate used for both bred dry cows and heifers.

tector $(\mu$-ECD) with a megabore column HP-MolSiv for $\mathrm{SF}_{6}$ measurement, with two $0.5 \mathrm{~mL}$ loop coupled to six way valve, strictly as the method described by Johnson et al. (1994, 2007). Columns were in parallel, each with its own sample loop. Elution time was of around $1.6 \mathrm{~min}$ for $\mathrm{CH}_{4}$ and $1.67 \mathrm{~min}$ for $\mathrm{SF}_{6}$ each replicate (three per sample).

After keeping away the canister from animals, they were pressurized up to around $0.17 \mathrm{MPa}$ (dilution of content) with nitrogen $99.99 \%$. Pressure before and after dilution were read with a digital manometer. Calibration curves were obtained using certified standard gases prepared by Praxair, containing $34 \pm 9 ; 91 \pm 9$

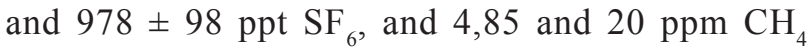
(Westberg et al., 1998; Johnson et al., 2007).

For a batch of capsules used in present study, these permeate typically 2.4 to $3.3 \mathrm{mg} \mathrm{SF}_{6} \mathrm{~d}^{-1}$. Ruminal methane flux was calculated in relation to the $\mathrm{SF}_{6}$ flux from capsules housed in the rumen, subtracting the background $\mathrm{CH}_{4}$ level in air (Westberg et al., 1998):

$\mathrm{Q}_{\mathrm{CH} 4}=\mathrm{Q}_{\mathrm{SF} 6} \times\left(\left[\mathrm{CH}_{4}\right]_{\mathrm{y}}-\left[\mathrm{CH}_{4}\right]_{\mathrm{b}}\right) /\left[\mathrm{SF}_{6}\right]$

where: $\mathrm{Q}_{\mathrm{CH} 4}=$ ruminal methane emission rate; $\mathrm{Q}_{\mathrm{SF} 6}=$ known capsule $\mathrm{SF}_{6}$ emission rate; $\left[\mathrm{CH}_{4}\right]_{\mathrm{y}}=$ canister methane concentration; $\left[\mathrm{CH}_{4}\right]_{\mathrm{b}}=$ background methane concentration; $\left[\mathrm{SF}_{6}\right]=$ concentration of $\mathrm{SF}_{6}$ in canister.

With the primary data, were calculated the $\mathrm{CH}_{4}$ emission per day and per kilogram of metabolic weight. Mean values of ten emission readings per replicate of each category were used since no great day-night emission differences were found. Also the $\mathrm{CH}_{4}$ emission per dry matter intake and organic matter per digestibility of dry matter and organic matter were calculated.

Analysis of variance was used to calculate the F value, and Tukey test was used for significant treatments, with the ANOVA procedure from the SAS
(1999). To evaluate the significance of categories in and between breeds the least square means were calculated, using the GLM procedure from the SAS.

\section{RESULTS AND DISCUSSION}

Methane production differed among breeds and categories, but no significant interaction occurred, either between seasons or among interactions with breeds and categories (Tables 5 and 6). When methane yield was related to metabolic weight $\left(\mathrm{g} \mathrm{kg}^{-0.75}\right)$ no differences appeared between breeds, nor among the interactions.

When variables related to dry matter intake (DMI), organic matter intake (OMI) and digestible organic mater intake (DOMI) were analyzed, differences occurred between breeds and among categories, and their interaction. For seasons only DMI presented differences for the interaction categories and season.

No differences were found between heifers of both breed for methane production nor when related to the metabolic weight, although differences occurred between pasture management system related to methane losses, and also to methane production related to DMI and OMI. Differences between seasons occurred also for DOMI, but not when related to methane losses.

Methane emission was greater for Holstein compared to the Crossbred (Table 7), perhaps explained by differences in animal body size, and more specifically by their organic matter intake potential, since there is a direct relation between methane production and digestible organic matter consumption, observed for Holstein. Significant methane losses occurred among categories, with lactating cows yielding more than dry cows, and these more than heifers.

Results related to pasture management intensity (extensive and intensive) and concentrate use, with heifers of both breed, did not show differences between 
Table 5 - Variance analysis output for breed, animal category and season.

\begin{tabular}{|c|c|c|c|c|c|c|c|c|c|}
\hline \multirow{3}{*}{ Sources } & \multicolumn{9}{|c|}{ SS of Dependent variables } \\
\hline & DF & DMI & OMI & DOMI & & & $\mathrm{CH}_{4}$ & & \\
\hline & & $\ldots$ & $---\mathrm{g} \mathrm{d}^{-1}-$ & & $\mathrm{g} \mathrm{d}^{-1}$ & $\mathrm{~g} \mathrm{~kg}^{-0.75}$ & $\begin{array}{l}\mathrm{g} \mathrm{kg}^{-1} \\
\text { DMI }\end{array}$ & $\begin{array}{l}\mathrm{g} \mathrm{kg}^{-1} \\
\mathrm{OMI}\end{array}$ & $\begin{array}{l}\mathrm{g} \mathrm{kg}^{-1} \\
\text { DOMI }\end{array}$ \\
\hline Block & 3 & $0.76 \mathrm{~ns}$ & $0.63 \mathrm{~ns}$ & $3.08 \mathrm{~ns}$ & $36,997 *$ & $2.82 *$ & $179.8 \mathrm{~ns}$ & $205.1 \mathrm{~ns}$ & $381.6^{*}$ \\
\hline Breed & 1 & $142.59 * *$ & $125.03 * *$ & $59.21 * *$ & $14,817 *$ & $0.36 \mathrm{~ns}$ & $96.9^{*}$ & $121.0 *$ & $582.3^{*}$ \\
\hline Category & 2 & $122.49 *$ & $110.19 *$ & $45.84 *$ & $141,780 *$ & $10.03 *$ & $173.6 \mathrm{~ns}$ & $182.5 \mathrm{~ns}$ & $515.3 \mathrm{~ns}$ \\
\hline Bre $\times$ Cat & 2 & $30.26 *$ & $29.08 *$ & $25.25 *$ & $11,987 \mathrm{~ns}$ & $0.56 \mathrm{~ns}$ & $3.8 \mathrm{~ns}$ & $6.2 \mathrm{~ns}$ & $170.5 \mathrm{~ns}$ \\
\hline Error (a) & 15 & 61.55 & 50.58 & 23.74 & 48,358 & 5.04 & 369.5 & 427.1 & 1335.2 \\
\hline Season & 1 & $0.19 \mathrm{~ns}$ & $0.66 \mathrm{~ns}$ & $0.15 \mathrm{~ns}$ & $7,613 \mathrm{~ns}$ & $1.69 *$ & $33.2 \mathrm{~ns}$ & $68.4 *$ & $225.0 *$ \\
\hline Bre $\times$ Sea & 1 & $0.20 \mathrm{~ns}$ & $0.01 \mathrm{~ns}$ & $0.09 \mathrm{~ns}$ & $4,596 \mathrm{~ns}$ & $0.95 *$ & $37.7 *$ & $38.0 \mathrm{~ns}$ & $163.5 *$ \\
\hline Cat $\times$ Sea & 2 & $14.92 *$ & $11.05 \mathrm{~ns}$ & $0.70 \mathrm{~ns}$ & $1,662 \mathrm{~ns}$ & $0.11 \mathrm{~ns}$ & $51.7 \mathrm{~ns}$ & $58.3 \mathrm{~ns}$ & 51.6ns \\
\hline Error (b) & 20 & 42.53 & 39.24 & 16.20 & 45,072 & 2.90 & 173.0 & 207.5 & 557.8 \\
\hline Total & 47 & 415.49 & 366.48 & 174.26 & 312,883 & 24.46 & $1,119.2$ & $1,314.2$ & $3,982.8$ \\
\hline $\mathrm{CV}(\%)$ & & 10.6 & 11.0 & 12.1 & 16.9 & 14.3 & 14.3 & 14.5 & 13.7 \\
\hline Mean & & 13.8 & 12.7 & 7.4 & 281.7 & 2.7 & 20.6 & 22.3 & 38.5 \\
\hline
\end{tabular}

Note: $*=$ Significant at a level of $5 \%(*)$ or $1 \%(* *) ; n s=$ not significant; SS = Sum of squares; DF = degrees of freedom; CV = coefficient of variation. $\mathrm{CH}_{4}=$ Methane production; DMI = Dry matter intake; OMI = Organic matter intake; DOMI = Digestible organic matter intake.

Table 6 - Variance analysis output for heifers in two systems of diet and pasture management, and season.

\begin{tabular}{|c|c|c|c|c|c|c|c|c|c|}
\hline \multirow{3}{*}{ Sources } & \multicolumn{9}{|c|}{ SS of Dependent variables } \\
\hline & DF & DMI & OMI & DOMI & & & $\mathrm{CH}_{4}$ & & \\
\hline & & - - - - & $\mathrm{g} \mathrm{d}^{-1}$ & & $\mathrm{~g} \mathrm{~d}^{-1}$ & $\mathrm{~g} \mathrm{~kg}^{-0.75}$ & $\begin{array}{l}\mathrm{g} \mathrm{kg}^{-1} \\
\mathrm{DMI}\end{array}$ & $\begin{array}{l}\mathrm{g} \mathrm{kg}^{-1} \\
\mathrm{OMI}\end{array}$ & $\begin{array}{l}\mathrm{g} \mathrm{kg}^{-1} \\
\text { DOMI }\end{array}$ \\
\hline Block & 3 & $12.09 *$ & $10.03 *$ & $11.24 *$ & $43,953^{*}$ & $3.11 *$ & $220.7 *$ & $262.3 *$ & $514.6 \mathrm{~ns}$ \\
\hline Breed & 1 & $31.11 *$ & $26.12 *$ & $7.06^{*}$ & $734 \mathrm{~ns}$ & $0.54 \mathrm{~ns}$ & $40.2 \mathrm{~ns}$ & $47.0 \mathrm{~ns}$ & $172.4 \mathrm{~ns}$ \\
\hline Category & 2 & $2.13 \mathrm{~ns}$ & $1.39 \mathrm{~ns}$ & $23.21 *$ & $15,061 *$ & $1.02 \mathrm{~ns}$ & $77.9 *$ & $97.2 *$ & $198.9 \mathrm{~ns}$ \\
\hline Bre $\times$ Cat & 2 & $2.36 \mathrm{~ns}$ & $1.90 \mathrm{~ns}$ & $0.85 \mathrm{~ns}$ & $1,231 \mathrm{~ns}$ & $0.00 \mathrm{~ns}$ & $0.2 \mathrm{~ns}$ & $0.2 \mathrm{~ns}$ & 12.1 \\
\hline Error (a) & 9 & 7.99 & 6.87 & 3.09 & 20,642 & 1.93 & 128.5 & 149.9 & 711.7 \\
\hline Season & 1 & $0.62 \mathrm{~ns}$ & $1.63 \mathrm{~ns}$ & $2.19 *$ & $1,857 \mathrm{~ns}$ & $0.39 \mathrm{~ns}$ & $29.8 \mathrm{~ns}$ & $48.2 \mathrm{~ns}$ & $18.7 \mathrm{~ns}$ \\
\hline Bre $\times$ Sea & 1 & $1.39 \mathrm{~ns}$ & $1.05 \mathrm{~ns}$ & $0.36 \mathrm{~ns}$ & $297 \mathrm{~ns}$ & $0.13 \mathrm{~ns}$ & $13.2 \mathrm{~ns}$ & $15.9 \mathrm{~ns}$ & $14.2 \mathrm{~ns}$ \\
\hline Sys $\times$ Sea & 2 & 0.82 & $1.09 \mathrm{~ns}$ & $4.37 \mathrm{~ns}$ & $263 \mathrm{~ns}$ & $0.00 \mathrm{~ns}$ & $0.4 \mathrm{~ns}$ & $1.2 \mathrm{~ns}$ & $218.2 \mathrm{~ns}$ \\
\hline Error (b) & 13 & 8.33 & 6.96 & 2.71 & 33,278 & 2.76 & 171.1 & 201.2 & 988.3 \\
\hline Total & 31 & 66.85 & 57.04 & 55.07 & 117,316 & 9.91 & 681.8 & 823.1 & $2,849.0$ \\
\hline CV (\%) & & 7.0 & 6.9 & 8.5 & 25.2 & 21.6 & 20.7 & 20.7 & 22.8 \\
\hline Mean & & 200.9 & 2.1 & 11.4 & 200.9 & 2.1 & 17.5 & 19.0 & 38.3 \\
\hline
\end{tabular}

Note: $*=$ Significant at a level of $5 \%, \mathrm{~ns}=$ not significand, $\mathrm{SS}=$ Sum of squares, $\mathrm{DF}=$ Degrees of freedom, CV $=$ Coefficient of variation $\mathrm{CH}_{4}=$ Methane production, DMI = Dry matter intake, OMI = Organic matter intake, DOMI = Digestible organic matter intake.

breeds, nor between seasons for the parameters related to methane production. Absence of differences between seasons may have resulted from small variations in forage quality (Table 3), even when reduced rainfall allowed lower forage availability in fall.

Data agree with those of Holter \& Young (1992), which pointed to differences in methane emission rates between breeds and animal categories, as function of differences in size of gastric compartments, and nu- tritional requirements. The category lactating cow with greater methane emission per animal, were also these categories with greater DOMI, pointing to a relation between these variables.

Taking into account characteristics of animals and adopted management of the herd, with supplementation of diet in the dry season, a mean value for potential yearly methane production by lactating and dry cows of $113.6 \mathrm{~kg}$ could be considered. This value is 
Table 7 - Methane production and feed intake as function of season, breed, category and management system.

\begin{tabular}{|c|c|c|c|c|c|c|c|c|}
\hline \multirow{2}{*}{ Treatment } & \multirow{2}{*}{\multicolumn{2}{|c|}{$\mathrm{CH}_{4}$}} & \multirow{2}{*}{ DMI } & \multirow{2}{*}{ OMI } & \multirow{2}{*}{ DOMI } & \multicolumn{3}{|c|}{$\mathrm{CH}_{4}$} \\
\hline & & & & & & DMI & OMI & DOMI \\
\hline & $\mathrm{g} \mathrm{d}^{-1}$ & $\mathrm{~g} \mathrm{~kg}^{-0.75} \mathrm{LW}$ & \multicolumn{3}{|c|}{ - } & \multicolumn{3}{|c|}{ - } \\
\hline & \multicolumn{8}{|c|}{ Summer } \\
\hline & \multicolumn{8}{|c|}{ Holstein } \\
\hline $\mathrm{LC}$ & 403.2 & 3.45 & 19.19 & 17.48 & 10.87 & 21.0 & 23.1 & 37.4 \\
\hline DC & 280.0 & 2.30 & 14.99 & 13.58 & 7.89 & 18.8 & 20.7 & 35.7 \\
\hline Hint & 222.2 & 2.11 & 12.78 & 11.60 & 6.81 & 17.4 & 19.2 & 32.9 \\
\hline \multirow[t]{2}{*}{ Hext } & 198.4 & 1.99 & 12.21 & 11.24 & 5.61 & 16.1 & 17.5 & 36.1 \\
\hline & \multicolumn{8}{|c|}{ Crossbred } \\
\hline LC & 332.6 & 3.57 & 13.66 & 12.56 & 6.59 & 22.0 & 23.0 & 36.6 \\
\hline DC & 294.5 & 2.90 & 12.55 & 11.39 & 6.62 & 16.9 & 18.1 & 32.2 \\
\hline Hint & 232.6 & 2.75 & 10.02 & 9.12 & 5.42 & 18.7 & 20.1 & 35.3 \\
\hline \multirow[t]{3}{*}{ Hext } & 181.0 & 2.12 & 10.20 & 9.39 & 4.69 & 13.5 & 14.5 & 39.5 \\
\hline & \multicolumn{8}{|c|}{ Fall } \\
\hline & \multicolumn{8}{|c|}{ Holstein } \\
\hline LC & 383.2 & 3.28 & 17.64 & 16.86 & 10.64 & 24.4 & 26.5 & 51.0 \\
\hline DC & 261.3 & 2.04 & 15.42 & 14.36 & 8.10 & 23.8 & 26.2 & 44.7 \\
\hline Hint & 245.0 & 2.25 & 13.13 & 12.23 & 6.90 & 22.9 & 25.2 & 42.4 \\
\hline \multirow[t]{2}{*}{ Hext } & 157.2 & 1.65 & 11.59 & 10.79 & 4.04 & 17.6 & 19.2 & 38.7 \\
\hline & \multicolumn{8}{|c|}{ Crossbred } \\
\hline LC & 296.3 & 2.92 & 11.81 & 10.94 & 6.37 & 25.6 & 27.6 & 47.4 \\
\hline DC & 238.4 & 2.21 & 13.56 & 12.62 & 7.10 & 17.8 & 19.1 & 33.8 \\
\hline Hint & 190.6 & 2.12 & 10.87 & 10.13 & 5.76 & 17.4 & 18.6 & 32.6 \\
\hline \multirow[t]{2}{*}{ Hext } & 180.3 & 2.05 & 10.74 & 10.00 & 3.73 & 16.7 & 18.0 & 48.8 \\
\hline & \multicolumn{8}{|c|}{ Mean of breed, intensive } \\
\hline Holstein & $299.3 \mathrm{a}$ & 2.74 & $15.52 \mathrm{a}$ & $14.4 \mathrm{a}$ & $8.53 \mathrm{a}$ & 19.1 & 20.7 & 35.0 \\
\hline Crossbred & $264.2 \mathrm{~b}$ & 2.57 & $12.08 \mathrm{~b}$ & $11.1 \mathrm{~b}$ & $6.31 \mathrm{~b}$ & 22.0 & 23.9 & 42.0 \\
\hline \multirow[t]{2}{*}{ MSD } & 28.6 & 0.23 & 0.88 & 0.84 & 0.54 & 1.8 & 1.9 & 3.2 \\
\hline & & & & of categ & intensive & & & \\
\hline LC & $353.8 \mathrm{a}$ & $3.30 \mathrm{a}$ & $15.57 \mathrm{a}$ & $14.46 \mathrm{a}$ & $8.61 \mathrm{a}$ & 23.2 & 25.0 & 43.1 \\
\hline DC & $268.8 \mathrm{~b}$ & $2.36 \mathrm{~b}$ & $14.13 \mathrm{~b}$ & $12.99 \mathrm{~b}$ & $7.43 \mathrm{~b}$ & 19.3 & 21.0 & 36.6 \\
\hline Hint & $222.6 \mathrm{c}$ & $2.31 \mathrm{~b}$ & $11.70 \mathrm{c}$ & $10.77 \mathrm{c}$ & $6.22 \mathrm{c}$ & 19.1 & 20.8 & 35.8 \\
\hline MSD & 35.0 & 0.28 & 1.08 & 1.03 & 0.66 & 2.2 & 2.4 & 3.9 \\
\hline & & & & n of sea & intensive & & & \\
\hline Summer & 294.3 & $2.85 \mathrm{a}$ & 13.86 & 12.85 & 7.48 & 23.4 & 23.5 & 40.7 \\
\hline Fall & 269.2 & $2.47 \mathrm{~b}$ & 13.74 & 12.62 & 7.37 & 19.7 & 21.1 & 36.3 \\
\hline MSD & 28.6 & 0.23 & 0.88 & 0.84 & 0.54 & 1.8 & 1.9 & 3.2 \\
\hline & & & & Mean o & & & & \\
\hline Hint & $222.6 \mathrm{a}$ & $2.31 \mathrm{a}$ & 11.70 & 10.77 & $6.22 \mathrm{a}$ & 19.1 & 20.8 & 35.8 \\
\hline Hext & $179.2 \mathrm{~b}$ & $1.95 \mathrm{~b}$ & 11.18 & 10.35 & $4.52 \mathrm{~b}$ & 16.0 & 17.3 & 40.8 \\
\hline MSD & 38.6 & 0.35 & 0.61 & 0.56 & 0.35 & 2.8 & 3.0 & 6.7 \\
\hline & & & & in of bre & systems & & & \\
\hline Holstein & 205.7 & 2.26 & $12.43 \mathrm{a}$ & $11.46 \mathrm{a}$ & $5.84 \mathrm{a}$ & 16.4 & 17.8 & 36.0 \\
\hline Crossbred & 196.1 & 2.00 & $10.46 \mathrm{~b}$ & $9.66 \mathrm{~b}$ & $4.90 \mathrm{~b}$ & 18.7 & 20.2 & 40.6 \\
\hline msd & 38.7 & 0.35 & 0.61 & 0.56 & 0.35 & 2.8 & 3.0 & 6.7 \\
\hline & & & & of seas & systems & & & \\
\hline Summer & 208.5 & 2.24 & 11.58 & 10.79 & $5.63 \mathrm{a}$ & 18.5 & 20.3 & 37.5 \\
\hline Fall & 193.3 & 2.02 & 11.30 & 10.34 & $5.11 \mathrm{~b}$ & 16.6 & 17.8 & 39.0 \\
\hline MSD & 38.6 & 0.35 & 0.61 & 0.56 & 0.35 & 2.8 & 3.0 & 6.7 \\
\hline
\end{tabular}

Note: $\mathrm{msd}=$ Minimum significant difference with Tukey test. Lower case letters at the right side of numbers in column mean significant difference among means. $\mathrm{CH}_{4}=$ Methane production, $\mathrm{DMI}=$ dry matter intake, $\mathrm{OMI}=$ organic matter intake, $\mathrm{DOMI}=$ digestible organic matter intake. $\mathrm{LC}$ and DC = Lactating and dry cow, Hint or Hext $=$ Heifers intensive or extensive. 
greater than that pointed by IPCC (2006) for grazing lactating cows in Latin America, $63 \mathrm{~kg}_{\mathrm{year}}{ }^{-1}$. These differences occur as function of the estimates of feed intake by animals, by animal breed, and variation in methodology used to estimate methane emissions. Potential milk yield by reference animals of IPCC (2006) inventory was of about $800 \mathrm{~kg}$ year $^{-1}$, much lower than the potential production of studied herd.

Methane production per unit of metabolic weight was not different between breed, but differences occurred among categories, with greatest values for lactating cows, showing a greater nutrient intake related to body weight. No differences occurred between dry cows and heifers, although differences occurred in dry matter and organic mater consumption, perhaps not great enough to affect methane emissions by these categories. Differences occurred between seasons, greater in summer, perhaps related to the characteristics of feed used in this season.

Parameter related to consumption of dry matter, organic matter and digestible organic matter were different for breeds and categories, greater for Holstein and lactating cows, because of the relation to animal weight and type of diet. Analyzing DMI results for lactating cows, when keeping away concentrate intake, point to estimated forage DMI of $2.4 \%$ live weight for Holstein lactating cows.

These results related with forage quality, mainly with the "in vitro" digestibility of organic matter, agree with findings of Noller (1997), who suggested an expected daily dry matter intake of $2 \%$ and $2.5 \%$ live weight by cows consuming forage with, respectively, $55 \%$ and $60 \%$ of TDN, with lower intake when forage availability is lower. For lactating Crossbred cows, daily forage intake was estimated in $2.1 \%$ live weight, probably overestimated since the forage OMIVD was of about $50 \%$, whose expected daily consumption would be of around $1.7 \%$ live weight. These differences could be explained by possible differences in forage quality of sampled material and the forage really consumed by animals, due to the selection capacity of Crossbred cattle.

Holstein lactating cows consuming greater amounts of digestible forage and concentrate, perhaps because of their greater nutritional requirement, than Crossbred lactating cows, produced more methane per day. A greater intake of digestible organic matter will increase $\mathrm{CH}_{4}$ emission per animal, but it will lead to greater production efficiency and therefore to a smaller methane emission per product unit (milk or beef) or productive cycle (Moss, 2001). Comparing mean milk production $\left(23.5 \mathrm{~L} \mathrm{~d}^{-1}\right)$ and methane emission $(393.2 \mathrm{~g}$ $\mathrm{d}^{-1}$ ) by Holstein lactating cows with that of the Crossbred $\left(11.5 \mathrm{~L} \mathrm{~d}^{-1}\right.$ of milk and $314 \mathrm{~g} \mathrm{~d}^{-1}$ of $\left.\mathrm{CH}_{4}\right)$ it is possible to calculate that $\mathrm{CH}_{4}$ production per liter of milk is about 16.7 and 27.3 for Holstein and Crossbred, respectively, corroborating above statements.

Methane production, DMI, OMI and DOMI were different between genetic groups, with greater $\mathrm{CH}_{4}$ emissions by the Crossbred, suggesting that Holstein were more efficient to use organic matter of feed. Variation in composition of diets, mainly forage quality and amount of concentrate, may contribute to these differences, being not necessarily an effect of breed, since organic matter of fiber will produce more methane than that of concentrates (Johnson \& Johnson, 1995).

Among categories, lactating cows produced more $\mathrm{CH}_{4}\left(\mathrm{~g} \mathrm{~kg}^{-1}\right.$ of DMI, OMI and DOMI) than dry cows and heifers. Methane production (as $\mathrm{g} \mathrm{kg}^{-1}$ of DMI) by lactating cows were $23.2 \mathrm{~g}$, a little more than that yielded by Cavanagh et al. (2008) in New Zealand (18.2 g), perhaps because of differences between diets and animals, although this data (18.2 g) is $15.7 \%$ lower than the reference value currently used in the New Zealand national inventory.

Differences occurred regarding methane production per unit of organic matter and digestible organic matter consumption between seasons, as a result of variation in feed quality, mainly consummated forage, although no differences for the amount of organic matter intake between seasons occurred, suggesting differences among animals. Considering the standard value of energy released by each unit of feed dry matter as 18.451 $\mathrm{MJ} \mathrm{kg}^{-1}$ (Ferrell, 1993) and the energy generated by methane as $0.05565 \mathrm{MJ} \mathrm{g}^{-1}$, it is possible to estimate the energy loss as methane percent of ingested crude energy (Ym) by Holstein lactating cows of about $6.4 \%$, mean value suggested by IPCC (2006) for dairy cows $(6.5 \pm 1 \%)$ when poorer feed is available. Values of Ym for Holstein and Crossbred animals were estimated to be about $5.8 \%$ and $6.6 \%$, respectively.

Heifers from the intensive system produced meanly $222.6 \mathrm{~g} \mathrm{~d}^{-1}$ of methane, more than heifers from the extensive system $\left(179.2 \mathrm{~g} \mathrm{~d}^{-1}\right)$, in accordance to greater DOMI and also considering that diet in the intensive system were enriched by concentrate, leaving to greater dry matter intake and methane emissions. Pastures of the extensive system, with lower forage quality and lower digestibility, suggest that daily methane yield per animal will be lower than in intensively managed system, although animal production will be jeopardized, leaving to longer production cycles, and therefore to greater total methane emissions during animals' productive life. Estimating the yearly potential of methane production by the extensive system $(65.4 \mathrm{~kg})$ it will be close to the IPCC (2006) reference for dairy cattle raised on pasture in Latin America $(63 \mathrm{~kg})$. 


\section{CONCLUSIONS}

Intensive managed pasture systems, with fertilized pasture and concentrate use, do generate more methane per day, but analysis need to consider the reduction of production cycle, with possibility of increased animal productivity.

Variations in methane emission among genetic groups, categories and production systems, point to the need of more stratified studies to attend the inventory on methane emissions of the Brazilian bovine cattle herd, due to distinct regional production characteristics in the country.

\section{ACKNOWLEDGEMENTS}

The research was funded by Financiadora de Estudos e Projetos (FINEP). T.T. Berchielli is recipient of CNPq productivity fellowship; to Johnson, $\mathrm{K}$ and Westberg, H. for technical support to the introduction of the $\mathrm{SF}_{6}$ method in Brazil.

\section{REFERENCES}

CAVANAGH, A.; McNAUGHTON, L.; CLARK, H.; GREAVES, C.; GOWAN, J.M.; PINARES-PATINO, C.; DALLEY, D.; VLAMING, B.; MOLANO, G. Methane emissions from grazing Jersey $\times$ Friesian dairy cows in mid lactation. Australian Journal of Experimental Agriculture, v.48, p.230-233, 2008.

ETHERIDGE, R.D.; PESTI, G.M.; FOSTER, E.H. A comparison of nitrogen values obtained utilizing the Kjeldahl nitrogen and Dumas combustion methodologies (Leco CNS 2000) on samples typical of an animal nutrition analytical laboratory. Animal Feed Science and Technology, v.73, p.21-28, 1998.

FERRELL, C.L. Metabolismo de la energía. In: CHURCH, D.C. EI rumiante: fisiología digestiva y nutricion. Zaragoza: Acribia, 1993. p.283-304.

HOLTER, J. B.; YOUNG, A. J. Nutrition, feeding and calves: methane prediction in dry and lactating Holstein cows. Journal of Dairy Science, v.75, p.2165-2175, 1992.

INTERGOVERNMENTAL PANEL ON CLIMATE CHANGE IPCC. 2006 IPCC guidelines for National Greenhouse Gas Inventories. In: EGGLESTON, H.S.; BUENDIA, L.; MIWA, K.; NGARA, T.; TANABE, K. (Ed) Agriculture, forestry and other land use. Hayama: Institute for Global Environmental Strategies, 2006. v.4. Available at: http:// www.ipcc-nggip.iges.or.jp/public/2006gl/vol4.html. Accessed 6 Sept. 2007.

JOHNSON, K.A.; JOHNSON, D.E. Methane emissions from cattle. Journal of Animal Science, v.73, p.2483-2492, 1995.

JOHNSON, K.; HUYLER, M.; WESTBERG, H.; LAMB, B.; ZIMMERMAN, P. Measurement of methane emissions from ruminant livestock using a $\mathrm{SF}_{6}$ tracer technique. Environmental Science Technology, v.28, p.359-362, 1994.

JOHNSON, K.A.; WESTBERG, H.H.; MICHAL, J.J.; COSSALMAN, $\mathrm{M}$.W. The $\mathrm{SF}_{6}$ tracer technique: methane measurement from ruminants. In: MAKKAR, H.P.S; VERCOE, P.E. (Ed) Measuring methane production from ruminants. New York: Springer, 2007. chap.3, 36p.

KÖPPEN, W. Climatologia. Buenos Aires: Panamericana, 1948. $478 \mathrm{p}$.

KURIHARA, M.; MAGNER, T.; HUNTER, R.A.; McCRABB, G.J. Methane production and energy partition of cattle in the tropics. British Journal of Nutrition, v.81, p.227-234, 1999.
LASSEY, K.R.; WALKER, C.F.; McMILLAN, A.M.S.; ULYATT, M.J. On the performance of $\mathrm{SF}_{6}$ permeation tubes used in determining methane emission from grazing livestock. Chemosphere - Global Change Science, v.3, p.367-376, 2001.

LASSEY, K.R.; PINARES-PATIÑO, C.S.; ULYATT, M.J. Methane emission by grazing livestock: some findings on emission determinants. In: HAM, J. van; BAEDE, A.P.M.; GUICHERIT, R.; WILliaMS-JACOBSE, J.G.F.M. (Ed.) Non-CO2 greenhouse gases: scientific understanding, control options and policy aspects. Rotterdam: Millpress, 2002. p.95-100.

LASSEY, K.R. Livestock methane emission and its perspective in the global methane cycle. Australian Journal of Experimental Agriculture, v.48, p.114-118, 2008.

MATHISON, G.W.; OKINE, E.K.; VAAGE, A.S.; KASKE, M.; MILLIGAN, L.P. Current understanding of the contribution of the propulsive activities in the forestomach to the flow of digesta. In: ENGELHARDT, W.V.; LEONHARD-MAREK, S.; BREVES, G.; GIESSECKE, D. (Ed) Ruminant physiology: digestion, metabolism, growth and reproduction. Stuttgart: Ferdinand Enke, 1995. p.23-41.

McMENIMAN, N.P. Methods of estimating intake of grazing animals. In: REUNIÃO ANUAL DA SOCIEDADE BRASILEIRA DE ZOOTECNIA, 34., Juiz de Fora, 1997. Anais. Juiz de Fora: Sociedade Brasileira de Zootecnia, 1997. p.131-168.

MOSS, A.R. Methane production by ruminants: literature review of I. Dietary manipulation to reduce methane production and II. Laboratory procedures for estimating methane potential of diets. Nutrition Abstracts and Reviews Series B, v.64, p.785-806, 1994.

MOSS, A.R. Enviromental control of methane production by ruminants. In: INTERNATIONAL CONFERENCE ON GREENHOUSE GASES AND ANIMAL AGRICULTURE, 1., Hokkaido 2001. Proceedings. Hokkaido: Greenhouse Gases and Animal Agriculture, 2001. p.35-43.

NATIONAL RESEARCH COUNCIL - NRC. Nutrient requirement of dairy cattle. 7. ed. Washington, D.C.: 2001. $381 \mathrm{p}$.

NOLLER, C.H. Nutritional requirements of grazing animals. In: SIMPÓSIO INTERNACIONAL SOBRE PRODUÇÃO ANIMAL EM PASTEJO, Viçosa, 1997. Anais. Viçosa: UFV, 1997. p.143172.

SAS INSTITUTE. SAS/STAT user's guide: version 8. Cary: SAS Institute, 1999. 1028p.

SMITH, P.; MARTINO, D.; CAI, Z.; GWARY, D.; JANZEN, H.; KUMAR, P. Agriculture. In: METZ, B. (Ed). Climate change 2007: mitigation. Contribution of Working Group III to the Fourth Assessment Report of the Intergovernmental Panel on Climate Change. Cambridge: Cambridge University Press, 2007.. $320 \mathrm{p}$.

SOEST, J.P. van. Nutritional ecology of the ruminant. 2.ed. Ithaca: Cornell University Press, 1994. 476p.

SOEST, J.P. van.; ROBERTSON, J.B.; LEWIS, B.A. Methods for dietary fiber, neutral detergent fiber, and nonstarch polysaccharides in relation to animal nutrition. Journal of Dairy Science, v.74, p.3583-3597, 1991.

TILLEY, J.M.; TERRY, R.A. A two stage technique for the in vitro digestion of forage crop. Journal of British Grassland Society, v.18, p.104-111, 1963.

WESTBERG, H.H.; JOHNSON, K.A.; COSSALMAN, M.W.; MICHAL, J.J. A $\mathbf{S F}_{6}$ tracer technique: methane measurement from ruminants. Pullman: Washington State University, 1998. $40 \mathrm{p}$

Received October 26, 2007

Accepted August 06, 2009 